\title{
SUBGLACIAL PROCESSES AT BONDHUSBREEN, NORWAY: PRELIMINARY RESULTS
}

\author{
by \\ Jon Ove Hagen, \\ (Geografisk Institutt, Universitetet i Oslo, Postboks 1042 Blindern, Oslo 3, Norway) \\ Bjørn Wold,
}

(Norges Vassdrags- og Elektrisitetsvesen, Hydrologisk Avdeling, Postboks 5091 Majorstua,

Oslo 3, Norway)

Olav Liestøl,

(Norsk Polarinstitutt, Postboks 138, 1330 Oslo Lufthavn, Norway)

Gunnar $\emptyset$ strem

(Norges Vassdrags- og Elektrisitetsvesen, Hydrologisk Avdeling, Postboks 5091 Majorstua,

Oslo 3, Norway)

and Johan Ludvig Sollid

(Geografisk Institutt, Universitetet i Oslo, Postboks 1042 Blindern, Oslo 3, Norway)

\section{ABSTRACT}

Subglacial hydrology, sediment transport, pressure, and temperature have been studied beneath approximately $160 \mathrm{~m}$ of ice at Bondhusbreen, an outlet glacier from Folgefonni in south-western Norway.

The volume of the mean annual water discharge passing through the study area is about $60 \times 10^{6} \mathrm{~m}^{3}$. Most of this water is diverted into a tunnel system in the rock beneath the glacier and used for hydroelectric power generation. At the beginning of the melt season, this water flows in multiple small channels, but later it collects in one or two main channels. The discharge of eroded material is about 7600 tonnes $\mathrm{a}^{-1}$. Of this, roughly $90 \%$ is transported by running water.

Pressure gauges and thermistors were installed at two sites under the glacier. Results from one of the sites indicated that ice can stagnate in some leeward positions, as almost no ice movement was recorded during most of the period of measurement and the pressure distribution was nearly hydrostatic. However, increased water pressure during the summer apparently resulted in the opening of subglacial cavities, adding a local up-glacier component to the flow at this site.

At another location, about $20 \mathrm{~m}$ up-glacier, non-hydrostatic differential pressures of up to 30 bar were recorded across an artificial dome-shaped obstacle. The flow at this location was more steady, in general, but rather dramatic effects were recorded when a boulder $0.3 \mathrm{~m}^{3}$ in size passed over the obstacle, destroying one of the pressure sensors. This sensor recorded a pressure of 90 bar before failing. The boulder was moving at a speed of about $40 \mathrm{~mm} \mathrm{~d} \mathrm{~d}^{-1}$, whereas the sliding velocity of the ice was $80 \mathrm{~mm}^{\prime} \mathrm{d}^{-1}$. Temperature measurements suggest that the difference in temperature across this obstacle was less than $0.03 \mathrm{deg}$, or an order of magnitude less than expected. This may mean that water was squeezed out of the ice on the stoss side of the obstacle as suggested by Robin (1976), and thus was not available to warm the lee-side ice by refreezing.

\section{INTRODUCTION}

A hydroelectric power station in south-western Norway (Fig.1) receives part of its water from Bondhusbreen, an outlet glacier from Folgefonni. Bondhusbreen extends down to $450 \mathrm{~m} \mathrm{a.s.1.,} \mathrm{but} \mathrm{the}$ collecting tunnel system for the power station is above $850 \mathrm{~m}$ a.s.l. Therefore mel twater from Bondhusbreen is collected subglacially. Tunnels for this purpose were driven through the rock beneath the glacier, with shafts extending up to the ice-rock interface under ice $160 \mathrm{~m}$ thick. A sedimentation chamber to remove coarse material from the diverted water was constructed in the tunnel system (Fig.2) (Wold and Østrem 1979[b]). The total volume of water diverted annually from the subglacial intake is about $60 \times 10^{6} \mathrm{~m}^{3}$.

Previous glaciological investigations at Bondhusbreen, made for planning purposes, have been reported by Pytte $(1963,1967,1969)$, Pytte and Østrem (1965), Pytte and Liestøl (1966), Østrem and Pytte (1968), Tvede (1973), Ziegler (1974), Haakensen (1975), and Kjeldsen (1975). Studies were continued during the period of construction of the tunnel system (Hagen 1977, Wold and Haakensen 1978 , Wold and Østrem 1979[a] and [b]). Since 1978, water discharge and sediment transport have been recorded at the point where meltwater enters the collecting tunnel under the glacier. 


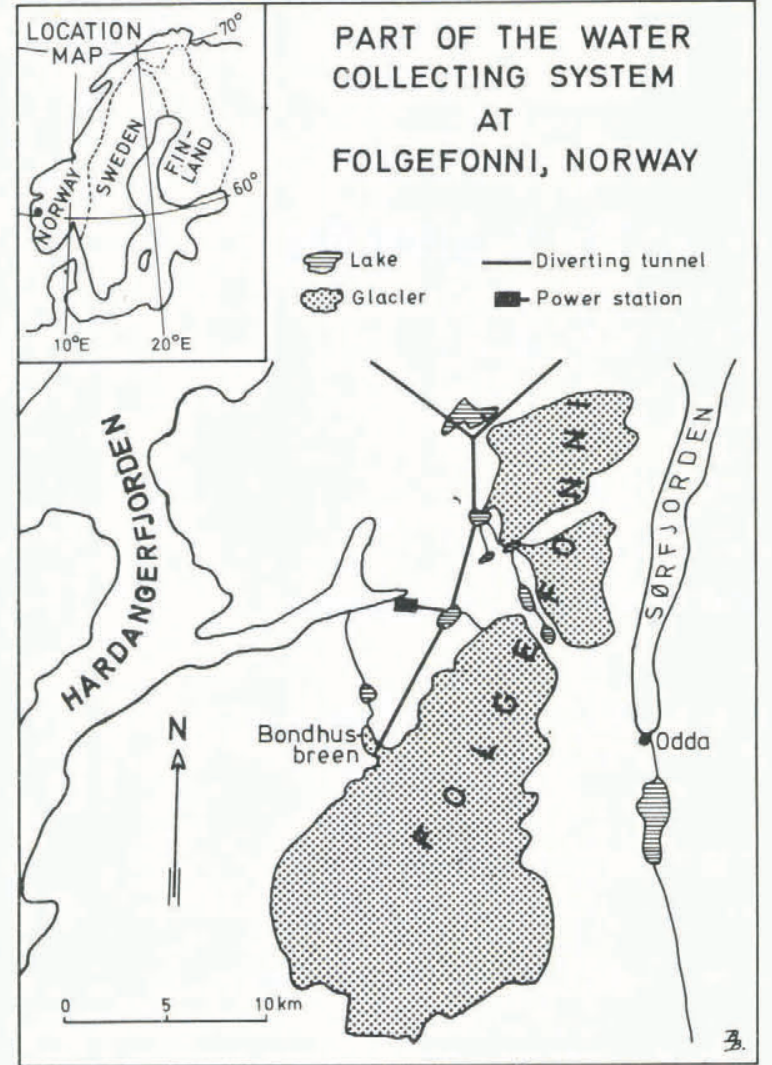

Fig.1. Location map showing a generalized outline of Folgefonni and part of the system of water collection for the hydroelectrical power station.

The tunnel system in the rock beneath Bondhusbreen provided access to the glacier bed and, thus, an exciting opportunity to make detailed measurements at the ice-rock interface. In order to make observations and to install instruments, ice tunnels were melted from the shafts along the glacier sole with the use of a hot-water system. Electrical cables from the instruments were run through bore holes from the ice-rock interface to the tunnel system in the rock, and thence to recorders. Once the instruments were installed, the ice tunnels closed by plastic deformation. The closing rate was 120 to $150 \mathrm{~mm} \mathrm{~d}^{-1}$ in tunnels with diameters of 1 to $3 \mathrm{~m}$.

The objectives of this paper are to describe methods used in this study and to present preliminary results. Further results will be presented in later papers (Hagen and others in preparation*). The studies were initiated by B Wold and the field work was performed during the period 1980 to 1982 , mainly by $\mathrm{J} O$ Hagen and $B$ Wold.

Previous observations and measurements in subglacial cavities (Carol 1947, Boulton and others 1979, Theakstone 1979, Vivian 1980, Anderson and others 1982, among others) have yièlded valuable information on subglacial processes. The experiments at Bondhusbreen extend these measurements to regions where the ice pressure is much greater and which were inaccessible up to now.

* Now in preparation and to be submitted:

Hagen J 0, Liestøl 0 , Sollid J L, Wold B, Østrem G Subglasiale undersøkelser under Bondhusbreen. Norsk Geografisk Tidsskrift
HYDROLOGY

Melting on Bondhusbreen starts normally in the middle of May, and $85 \%$ of the total discharge follows during the summer period from June to September. A definite decrease in discharge occurs between 0ctober and December. Thereafter a stable discharge of 50 to $2501 \mathrm{~s}^{-1}$ is observed during the winter period from January to April. The decreasing discharge during the autumn, after surface melting has ceased, is inferred to be largely from water stored in the glacier during the summer. The stable winter flow is interpreted to be water released from storage in the glacier and in the lake, Holmavatn. Melting caused by frictional and geothermal heat is at least an order of magnitude less than the observed flow.

The volume of the mean annual discharge during the years 1978 to 1981 was $60 \times 10^{6} \mathrm{~m}^{3}$. Of this, $10 \%$ originates from Holmavatn (Fig.2). Tracer experiments showed that the total run-off from this lake drains into the diverted tunnel system at intake (3) in Figure 2. This intake shaft catches about $90 \%$ of the water, whereas about $10 \%$ runs through shaft (1) and a minor amount, often under high pressure, comes through small drill holes in the bedrock. Some of the latter are relatively far from the main intakes. The entire winter discharge drains through the main intake at (3) in one single concentrated stream.

During the first days of the melt season, water appears to flow in multiple small intra- and subglacial channels. Later, the discharge gradually stabilizes in the main channels. Measurements at the glacier front indicated that almost all available water above the intake area was caught by the subglacial intakes.

\section{SEDIMENT TRANSPORT}

Sediment transport in the diverted water has been measured since 1978 (Kjeldsen 1979, 1980, 1981). Annual transport of coarse inaterial ranged from $2.8 \times 10^{3}$ to $5.2 \times 10^{3}$ tonnes. Annual transport of suspended material is about $4 \times 10^{3}$ tonnes, so the total mean annual transport amounts to about $7.6 \times 10^{3}$ tonnes. The amount of solid matter transported varies with water discharge and frequency of flash floods. The concentration of suspended sediment ranges normally from 0.015 to $0.070 \mathrm{~kg} \mathrm{~m}^{-3}$ increasing to a maximum of $0.785 \mathrm{~kg} \mathrm{~m}^{-3}$ during flash floods.

The content of solid material incorporated in the ice was determined by collecting ice samples, each of about $0.01 \mathrm{~m}^{3}$ from different places in the tunnels. These samples contained, in general, much more debris than the water did, the greatest concentration being about $60 \mathrm{~kg} \mathrm{~m}^{-3}$ (Fig.3). The greatest concentrations occurred in a layer 1 to $2 \mathrm{~m}$ thick at the sole; the amount decreased rapidly upwards. However, the cleanest basal ice was located near what is inferred to be the normal course of a subglacial water channel; this ice had a total debris content of only $0.030 \mathrm{~kg} \mathrm{~m}^{-3}$. In order to estimate the concentration of material likely to be suspended, the coarser (diameter $>0.5 \mathrm{~mm}$ ) particles were excluded and the concentration data replotted in Figure 4 . The maximum concentration of this material was about $15 \mathrm{~kg} \mathrm{~m}^{-3}$.

It is inferred that the ice near the subglacial river is clean because the running water melts the surrounding dirty glacial ice, resulting in inflow of cleaner ice from above. Large increases in sediment transport which are observed during floods are partly due to melting of debris-filled ice outside the ordinary channel.

If a subglacial stream crosses more or less diagonally over the glacier bed, ice will move across the stream course. Melting of this basal ice will then release debris to the stream. Such conditions will affect the mode of transport of the debris, i.e. whether it is transported englacially or by the subglacial water.

The amount of material transported englacially 


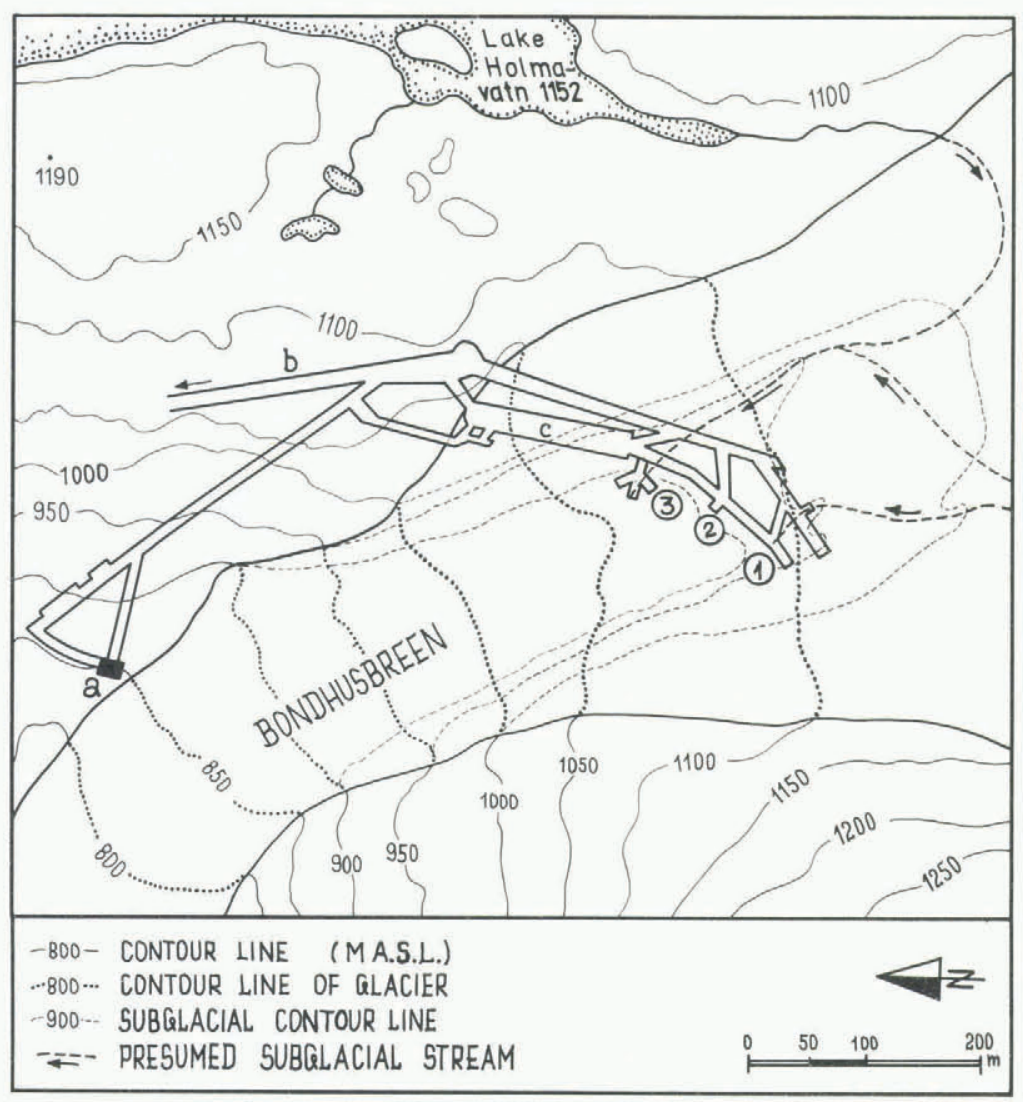

Fig.2. The tunnel system at Bondhusbreen. The subglacial terrain and streams are indicated. (a): helicopter platform and living quarters, (b): tunnel for water diversion, (c): sedimentation chamber. Intake shafts are represented by (1), (2) and (3).

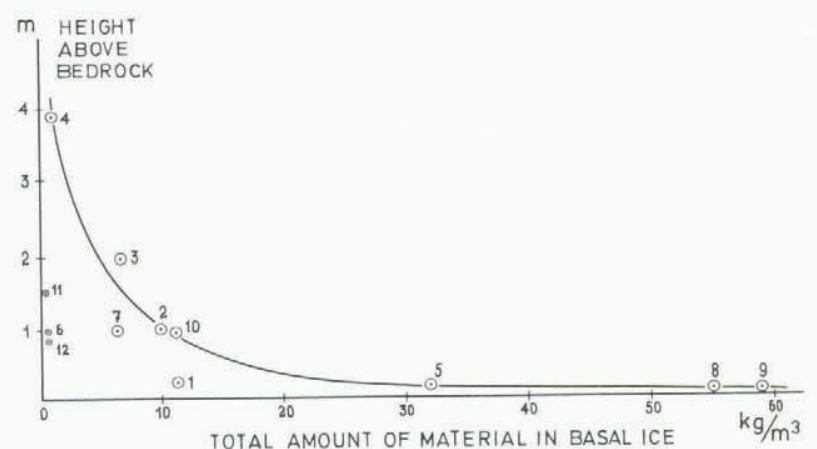

Fig.3. Distribution of material load in the basal ice. Samples 6,11 and 12 represent clean ice close to the subglacial stream shown in Figure 5.

can be calculated approximately by multiplying the debris content of the basal ice by a mean annual velocity of $30 \mathrm{~m} \mathrm{a}^{-1}$ and by the width of the glacier. Comparison of this value with the measured transport in the subglacial stream suggests that only $10 \%$ of the transport occurs englacially while $90 \%$ is transported in the river. Movement of subglacial moraine, if any, is not included in this calculation.

\section{PRESSURE MEASUREMENTS}

Ice pressures were measured by ten sensors ( $P_{1}$ to $\left.P_{10}\right)$ in three different installations (Figs.5 and 6$) . P_{1}, P_{2}$ and $P_{3}$ were mounted in an artificial

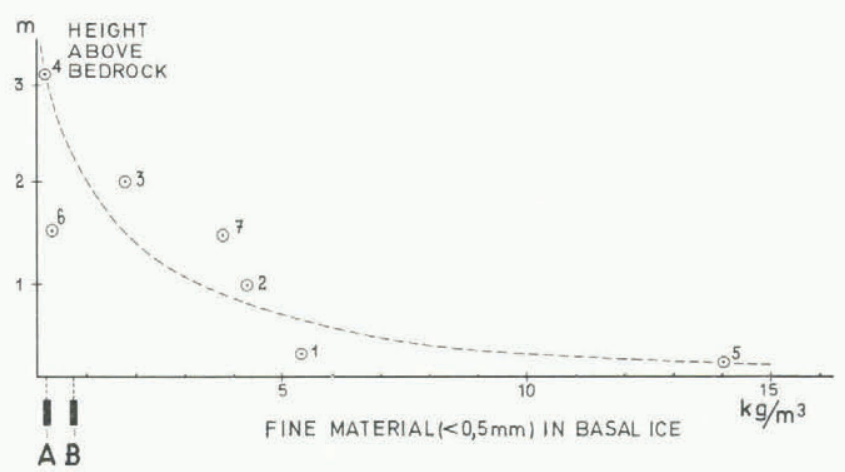

Fig.4. Fine material (diameter $<0.5 \mathrm{~mm}$ ) load in the basal ice compared to the amount of suspended load (diameter $<0.5 \mathrm{~mm}$ ) in the subglacial stream during (A) normal discharge and (B) flood discharge.

roche moutonnée in December 1980 (Fig.7). This construction was made of steel bolted to the bedrock and filled with reinforced concrete. A teflon sheet $2 \mathrm{~mm}$ thick covered the top of the construction in order to protect the sensors. This protection was removed from $P_{1}$ and $P_{2}$ during the suminer of 1981 , probably by scouring. The sensors were oriented with $P_{2}$ parallel to the general rock slope $\left(30^{\circ}\right)$ in the area, $P_{1}$ inclined $4^{8}$ down-glacier, and $P_{3}$ inclined $65^{\circ}$ down-glacier.

Sensors $\mathrm{P}_{4}$ and $\mathrm{P}_{5}$ were mounted at inclinations of $38^{\circ}$ and $86^{\circ}$, respectively, in shallow cavities hollowed out of the bedrock surface slightly up- 


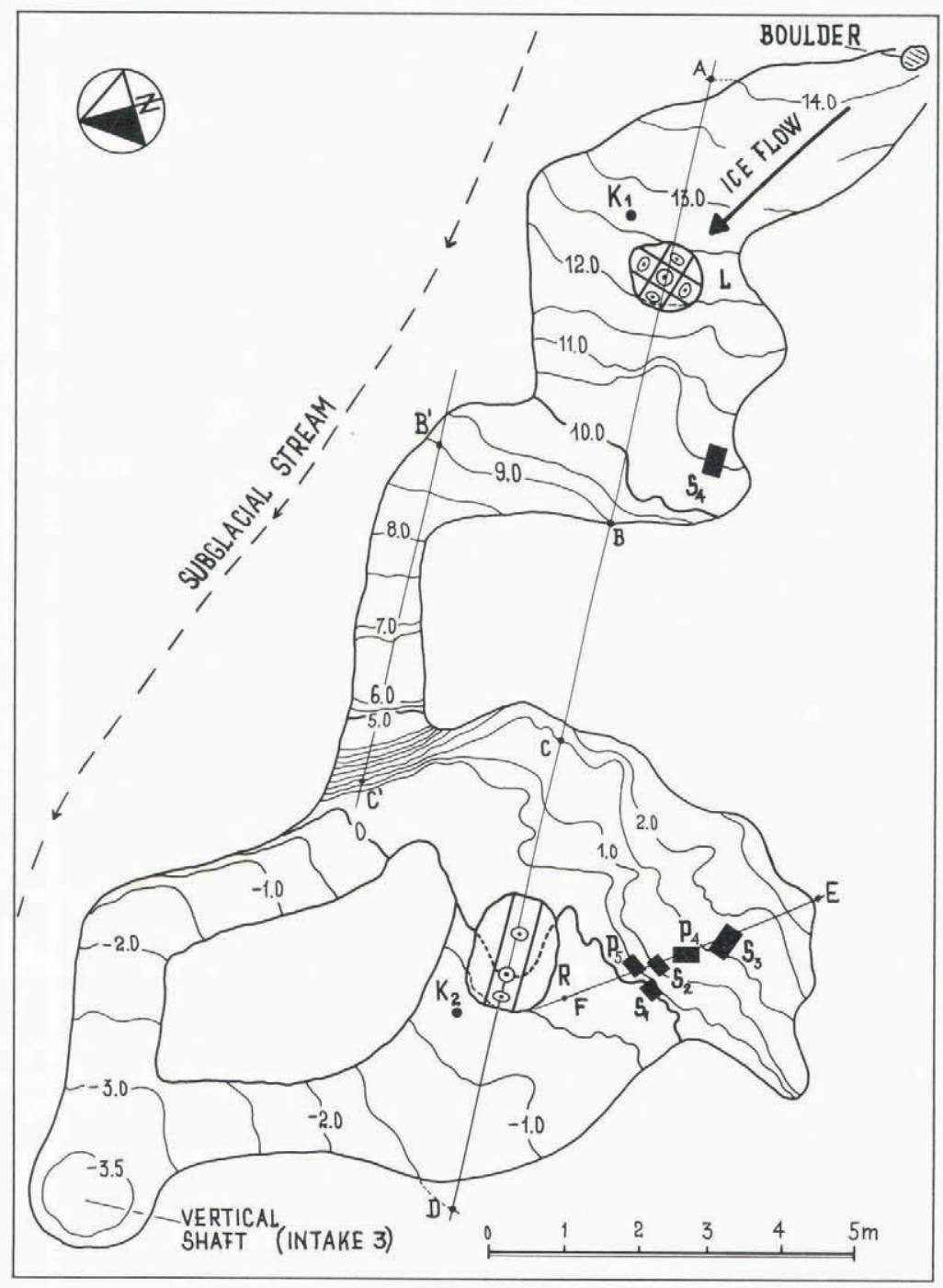

Fig.5. The tunnel and ice cavities melted out in the vicinity of intake (3) (Fig.2), showing the terrain and the position of the instruments. R: artificial roche moutonnée, L: dome-shaped construction, $\mathrm{P}_{4}$ and $\mathrm{P}_{5}$ : pressure gauges in the bedrock, $\mathrm{S}$ : strain gauges, $\mathrm{K}_{1}$ and $\mathrm{K}_{2}$ : small spheres with strain gauges and thermistors ( $S$ and $K$ are not described in this paper). Contours are on the glacier bed. Contour interval is is $0.5 \mathrm{~m}$.

glacier from the roche moutonnée in May 1981 (Figs. 5 and 8 ).

In December 1981, another subglacial tunnel was excavated up-glacier from the roche moutonnee. During this tunnelling, an almost vertical bedrock wall was found only a few metres upstream from sensors $P_{1}$ to $P_{5}$ (Figs.5 and 6). In the upper part of the tunnel a dome-shaped construction of steel and reinforced concrete, containing five pressure sensors $P_{6}$ to $P_{10}$ was placed on the bedrock (Fig.9). The bedrock in this area had a general slope of $35^{\circ}$. The sensors were placed symmetrically to simplify the interpretation of pressure and ice flow. The top sensor $\left(\mathrm{P}_{7}\right)$ was parallel to the general bedrock slope, the others dipped $15^{\circ}$ relative to $P_{7}$.

The pressure sensors used were standard instruments employing a vibrating wire system (Fig.10). They were calibrated at $0^{\circ} \mathrm{C}$ and had an accuracy of $\pm 1 \%$. Although the signals were recorded some distance from the sensors, the vibrating wire system is so designed that resistance in the wires and interference from spurious electrical fields do not influence the accuracy. Pressures were recorded at intervals of $1 \mathrm{~h}$, using a digital data-logger. This recording frequency is considered to be adequate for present purposes. As the study area (Figs.5 and 6) was situated under the upper part of a major ice fall, where surface velocities reach 0.30 to $0.35 \mathrm{~m} \mathrm{~d}^{-1}$, relatively rapid movement and high dynamic pressures were expected at the bottom of the glacier. The hydrostatic pressure under $160 \mathrm{~m}$ of ice is about 14 bar, so the pressure sensors were designed to span the range from 0 to about 50 bar.

It was intended that the main axis of each group of sensors should be parallel to the direction of movement of the basal ice. To this end, glacial striae were sought in the areas of the installations, and, upon re-opening of the tunnels, care was taken to observe the directions of striae on the various constructions. Directions on the same rock face showed local variations of about $30^{\circ}$, and some striae differed from the direction of ice fiow on the surface by $50^{\circ}$. Data presented below suggest that such variability was also a natural feature of the flow field at this location.

The subglacial stream shown in Figure 5 plays an 


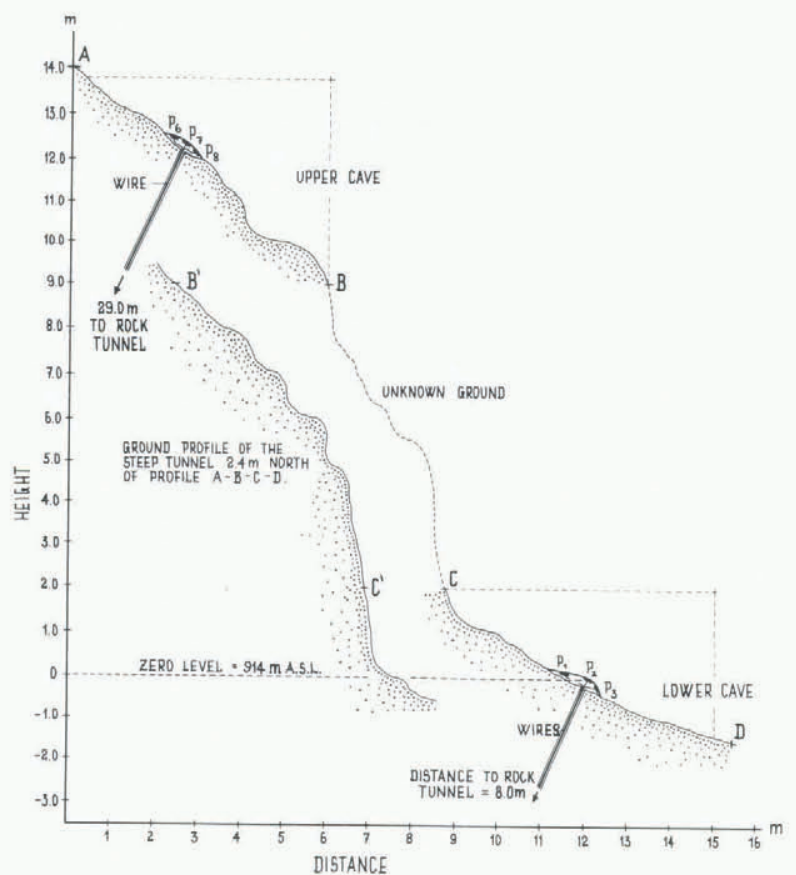

Fig.6. Longitudinal profiles on the bedrock. Locations shown in Figure 5.

important role in our interpretation of the pressure measurements. This stream appears to remain in approximately the location shown throughout the year, as evidence for its existence has been found on a number of occasions. In December 1981, for example, the stream could be heard from the artificial tunnel, and in two places water from it leaked into this tunnel. During the winter period from January to April 1981 , sensor $P_{1}$ recorded a stable pressure of 18 to 19 bar. Sensor $P_{2}$ normally showed a pressure between 17 and 18 bar, but there were several sudden decreases of about 2 bar over a period of an hour or so, followed by a slow increase during the following 25 to $30 \mathrm{~h}$. Sensor $\mathrm{P}_{3}$ recorded a pressure of 16 to 17 bar for several weeks, and then slowly decreased to 13 to 14 bar. This sensor showed a number of abrupt decreases of about 1 bar, lasting for 1 to over $30 \mathrm{~h}$, followed by equally abrupt increases. Figure 11, covering the period from 9 to 16 March 1981, i1lustrates these features.

During the summer season of May to October 1981, relatively even pressures of 16 to 17 bar were recorded on all three sensors on the roche moutonnée. However, during long periods $\mathrm{P}_{3}$ had a higher pressure than $P_{1}$ (Fig.12, 10-11 July 1981). This suggests slow ice motion towards the subglacial water channel where the continuously melting ice is presumably replaced by plastic inflow. Alternatively, it could possibly represent some sort of large-scale lee-side effect in the lee of the cliff up-glacier from the installation (Figs. 5 and 6 ).

These recordings suggest that the flow of ice along the sole at this location must be very slow. Measurements of sliding velocity here, using a segmented wooden rod inserted into the ice through a bore hole in the rock and later re-excavated, showed a velocity of less than $2 \mathrm{~mm} \mathrm{~d}^{-1}$ during spring. However, there must also be a dynamic effect since the pressure was consistently 3 to 4 bar above the hydrostatic pressure during long periods.

During the summer, disturbances were also observed during periods of increased water discharge which were presumably accompanied by widening of the subglacial stream. An example of this is shown in Figure 12. The pressure at all three sensors increased on $12 \mathrm{July}$

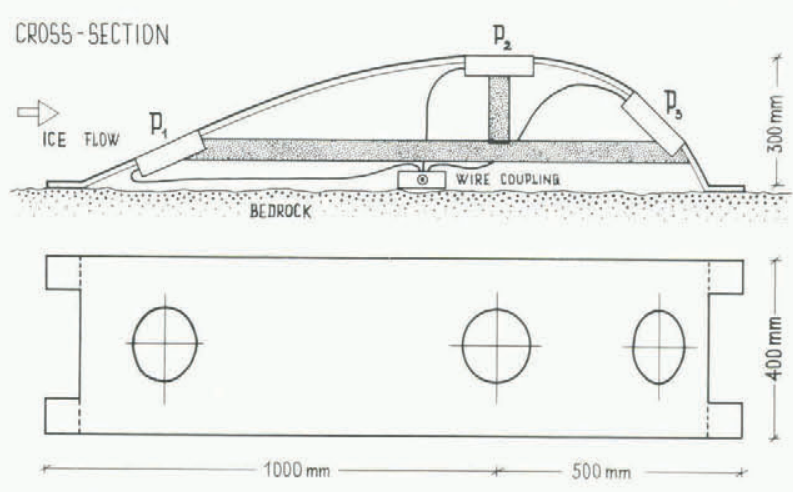

PLAN PROJECTION

Fig.7. Construction of roche moutonnée with pressure gauges $P_{1}, P_{2}$ and $P_{3}$.

1981 and then fell suddenly to zero. It is supposed that the increase in pressure was due to transfer of pressure to the roche moutonnée as an open tunnel or cavity (at atmosphere pressure due to the proximity of the intake at (3)) migrated laterally toward the roche moutonnée. The decrease in pressure would then represent uncovering of the sensors as the cavity passed successively over them from $P_{1}$ to $P_{3}$. Such a pressure variation would be consistent with Weertman's (1972) theoretical solution for the pressure distribution around a subglacial channel. This cavity could have been formed by lateral migration of the stream channel. The water discharge increased from 3 to $8.5 \mathrm{~m}^{3} \mathrm{~s}^{-1}$ in a period of seven days before the event shown in Figure 12.

It is interesting to note that as the ice re-covered the roche moutonnée it moved up-glacier, reaching $P_{3}$ first and $P_{1}$ last.

The pressure stabilized during the fall and winter of 1981-82. $P_{3}$ initially showed a somewhat higher pressure than $P_{1}$ but this pressure distribution changed slowly, so that by the beginning of March 1982, the situation was as follows: 16 bar at $P_{1}, 16.5$ bar at $P_{2}, 11$ bar at $P_{3}, P_{2}$ being the highest.

Sensors $\mathrm{P}_{4}$ and $\mathrm{P}_{5}$ (Fig.8) were more stable than $P_{1}, P_{2}$ and $P_{3} . P_{4}$ showed variations between 14 and 18 bar, and $P_{5}$ between 8 and 14 bar. The difference between these two sensors was initially 4 to 5 bar,

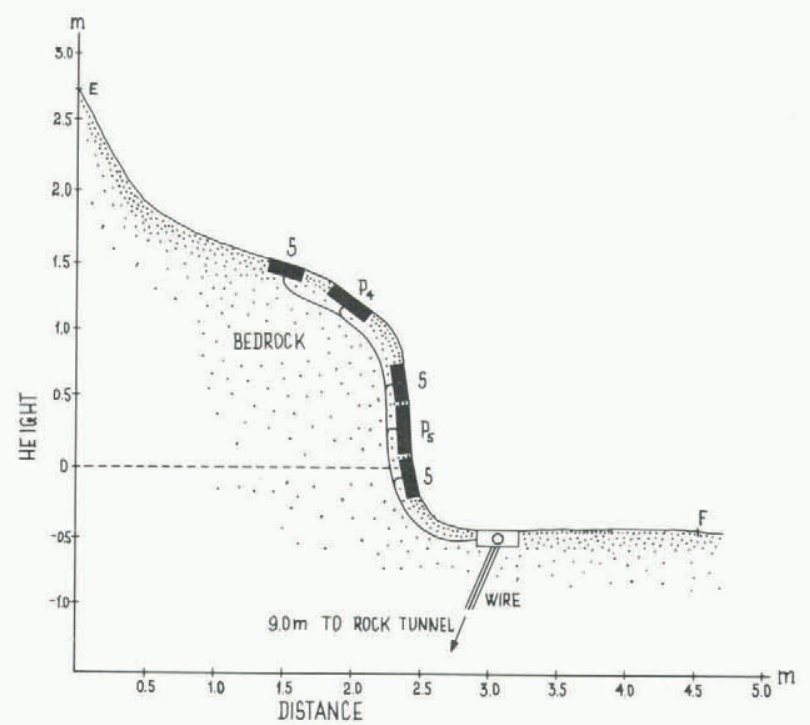

Fig.8. Cross-section along profile EF in Figure 5. 
CROSS - SECTION
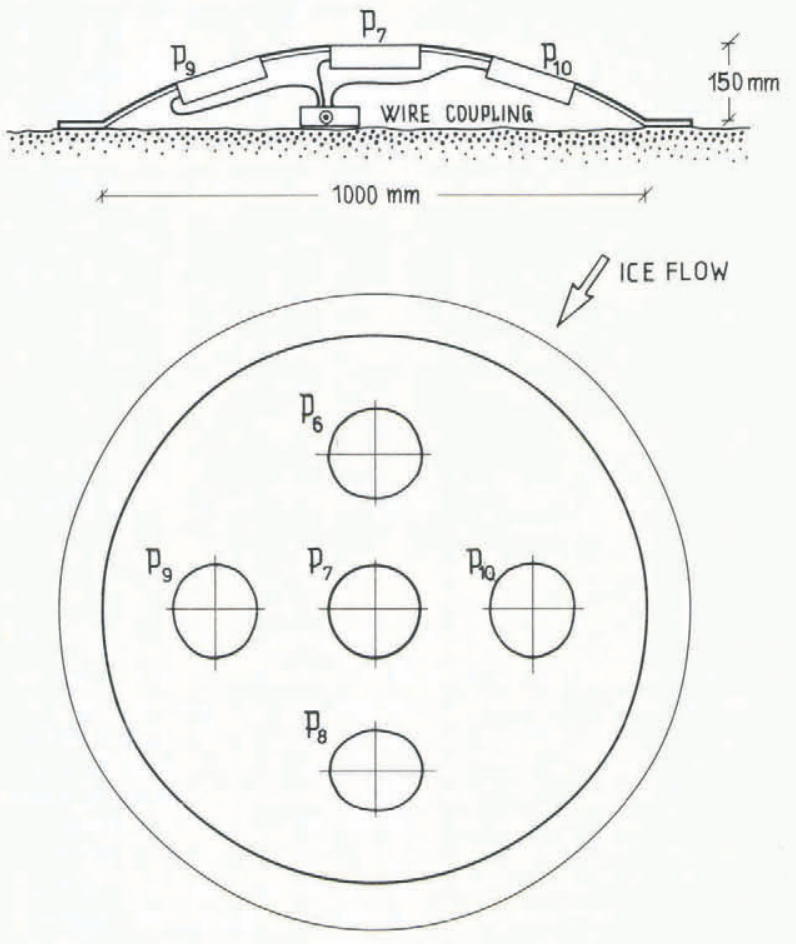

PLAN PROJECTION

Fig.9. Dome-shaped construction with pressure gauges $\mathrm{P}_{6}$ to $\mathrm{P}_{10}$.

reflecting the leeward position of $P_{5}$. This difference gradually decreased during the fall and winter, finally reaching zero near the end of March 1982.

Although the pressure at $P_{5}$ was never below about 8 bar, separation of the ice from the bed apparently occurs here, as a light-brown iron-manganese(?) precipitate was observed in leeward positions on the adjacent rock. It is suggested that these precipitates form in subglacial waterfilled cavities (Andersen and Sollid 1971. Sollid 1980). Separation is possible in such situations if the water pressure is high enough (e.g. Kamb 1970: 720).

Quite different pressure conditions were observed at the upper dome-shaped construction (Figs.5 and 9). During the period from January to April 1982 relatively stable readings were obtained, 26 to 29 bar at $P_{6}, 7$ to 11 bar at $P_{7}$, zero at $P_{8}, 4$ to 7 bar at $P_{9}$, and 19 to 21 bar at $P_{10}$ (Fig.13). There was an osvious "stoss" effect on $P_{6}$ and $P_{10}$, and a "lee" effect on $\mathrm{P}_{8}$ and $\mathrm{P}_{9}$. All leeward sensors indicated more variable pressures than the stoss-side ones.

This period of stability ended on 12 April 1982 , when the upper sensor $\mathrm{P}_{6}$ experienced a dramatic increase in pressure to 90 bar before it broke (Fig.14). It is presumed that a boulder of about $0.3 \mathrm{~m}^{3}$, which was observed about $4.3 \mathrm{~m}$ up-glacier from the sensor in December 1981, moved across the sensor. In connection with this event, disturbances were observed on the other sensors. A study of the pressure variations (Fig.14) suggests that the boulder hit $P_{5}$ and destroyed $i t$, and may have then moved over the construction between $\mathrm{P}_{7}$ and $\mathrm{P}_{9}$ (Fig.9).

The mean velocity of the boulder was calculated to be $40 \mathrm{~mm} \mathrm{~d}^{-1}$, based on its initial position (Fig.5) and on the interval of time required for it to move to the sensor. The ice velocity, measured by a wire running from a block of wood fixed in the ice, down through a bore hole, and thence to a recorder in the tunnels, was $80 \mathrm{~mm} \mathrm{~d}^{-1}$ in June 1981 . Obviously boulders at the sole of the glacier should move more slowly than the glacier ice itself, due to friction against the bedrock. This results in a leeward effect in front of the boulders, which can be clearly seen by the pressure drop at $\mathrm{P}_{6}$ approximately two weeks before the boulder reached the sensor. Apparently the the lee effect extended roughly $0.5 \mathrm{~m}$, or somewhat less than the diameter of the boulder $(0.7 \mathrm{~m})$, in front of the boulder.

These pressure observations suggest that flow in the basal ice is unsteady on an annual time scale, with natural cavities opening and closing, and with direction of flow changing radically. The latter is supported by observations of striae on the glacier bed exposed in the artificial tunnels. Striae on the same rock face frequently differed in orientation by $30^{\circ}$, and from one face to another; over a distance of only a few metres, they could vary by $120^{\circ}$. For example, the roche moutonnée was originally aligned parallel to striae on the rock surface on which it was placed, but striae that developed on the roche moutonnee itself suggested flow, which actually had an up-glacier component, at an angle of $120^{\circ}$ with respect to the axis of the construction. These could have been made during closure either of the artificial cavity or of cavities formed during the summer. Striae up-glacier from the dome construction suggested that the boulder (Fig.5) would pass a couple of metres to the south of the installation, but instead the boulder appears to have hit the construction directly.

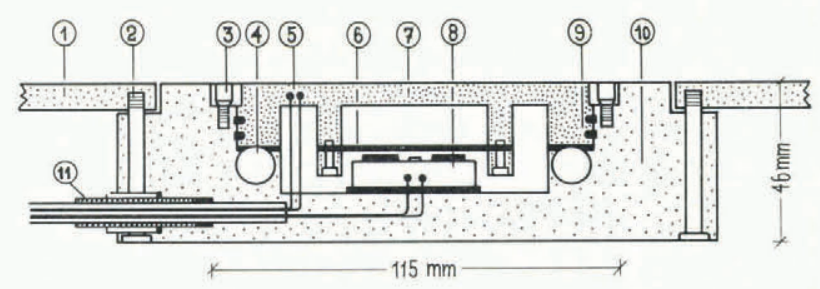

Fig.10. Cross-section through a pressure gauge.

(1): steel plate,

(2): recessed boit,

(3): binding ring with recessed screw,

(4): steel ball, holding the membrane,

(5): thermistors drilled into membrane,

(6): vibrating wire,

(7): membrane with steel rods,

(8): magnetic system,

(9): rubber gaskets,

(10): steel box,

(11): water-tight seal around electric wires.

The vibrating wire is excited by the magnetic system. The change in frequency is directly related to the change in pressure applied to the membrane. Pressure $P$ is then given by $P=K\left(F^{2}-F_{0}{ }^{2}\right.$ where $K$ is a calibration constant and $F$ and $F$ are the frequencies before and after the pressure is applied.

\section{TEMPERATURE MEASUREMENTS}

Each pressure sensor also contained one or two thermistors placed about $2 \mathrm{~mm}$ under the surface of the steel membrane. The thermistors were Fenwall UNI-curve, UUD 23JI with a standard resistance of $760 \Omega$ at $0^{\circ} \mathrm{C}$, and $\mathrm{R} / \Delta \mathrm{T}=30 \Omega$ per ${ }^{\circ} \mathrm{C}$.

Unfortunately, for technical reasons, the temperature measurements were never completely successful. Thermistors subsequently placed in the dome construction were carefully calibrated, but water gained access to the connection boxes, so consistent results were obtained for only a few of the thermistors, and for only part of the duration of the experinents. Measurements of temperature differences $\Delta T$ were more stable and reliable than the measurements of temperature $T$ itself. 


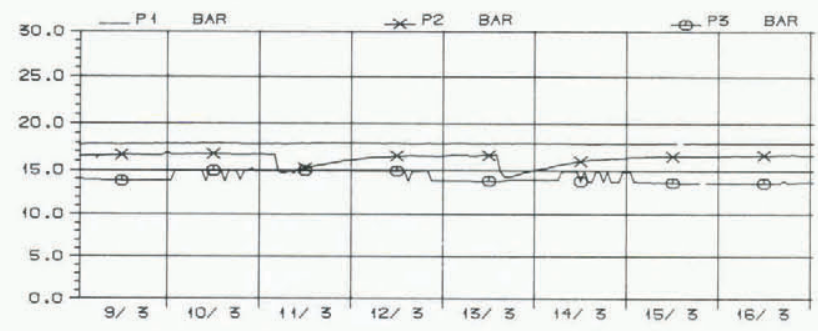

Fig.11. Pressure recordings from the roche moutonnée in March 1981.

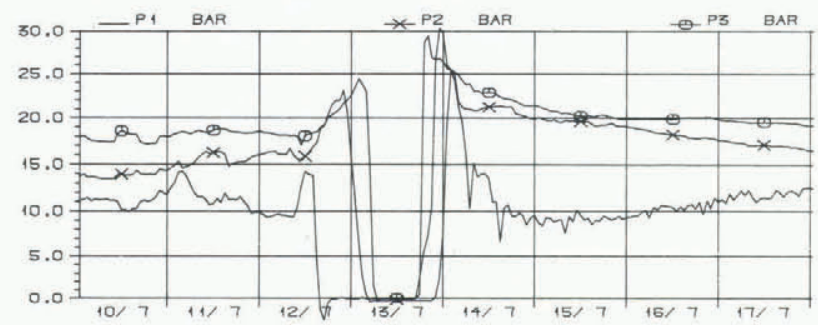

Fig.12. Pressure recordings from a period in July 1982 when a cavity was present.
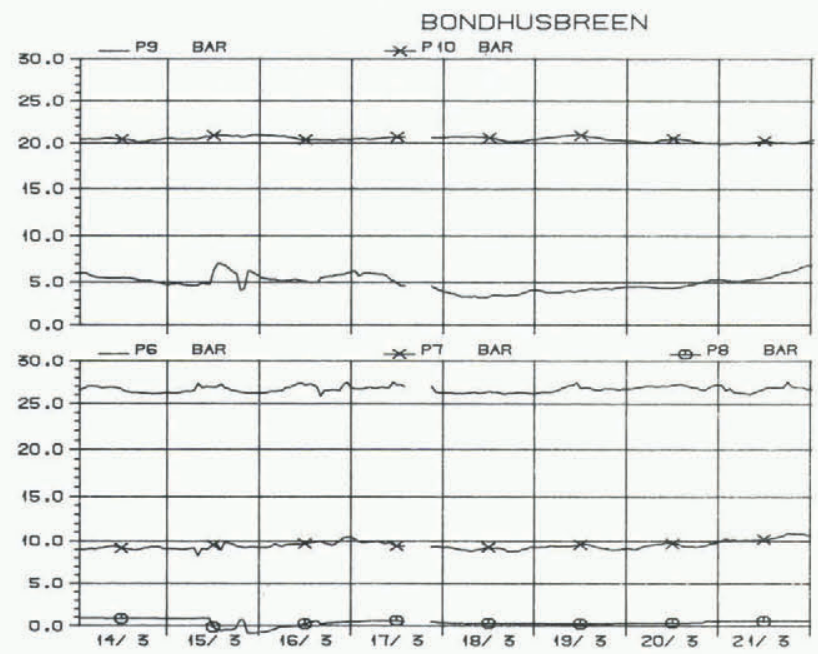

Fig.13. Pressure recordings from the dome-shaped construction in March 1982.

Some of the results from thermistors in sensors $\mathrm{P}_{4}$ and $\mathrm{P}_{5}$ (Fig.8) appear to be reliable. The temperature difference $\Delta T\left(P_{5}-P_{4}\right)$, quickly stablized at about $0.05^{\circ} \mathrm{C}, \mathrm{P}_{4}$ being $0.05^{\circ} \mathrm{C}$ colder than $\mathrm{P}_{5}$. This is consistent with expectations, as the difference in pressure between these two positions was then about 5 bar, with $P_{4}$ reading about 15 bar and $P_{5}$ about 10 bar. In the winter of 1982 , the pressures at $P_{4}$ and $P_{5}$ were nearly equal at about 14 bar, and $\Delta T\left(P_{5}-P_{4}\right)$ was nearly $0(<0.015 \mathrm{deg})$.

In the dome construction, we intended to measure temperature differences between $P_{6}$ and $P_{8}$ as well as between $\mathrm{P}_{9}$ and $\mathrm{P}_{10}$, and absolute temperatures at $\mathrm{P}_{6}$, $P_{7}$, and $P_{8}$. The temperature difference $\Delta T\left(P_{6}-P_{8}\right)$ seems to have been stable for several weeks in the winter, $P_{6}$ being about 0.025 deg lower than $P_{8}$. The pressure difference $\Delta P\left(P_{6}-P_{8}\right)$ was almost constant at 28 bar. Similarly the difference $\Delta T\left(P_{10}-P_{9}\right)$ was $0.01 \mathrm{deg}, P_{10}$ being colder, while $\Delta P\left(P_{10}-P_{9}\right)$ was 10 to 12 bar. These results suggest that large differences in pressure do not produce as large differences in temperature as expected. This may be because water is squeezed out of the ice on the stoss side (Robin 1976), so that

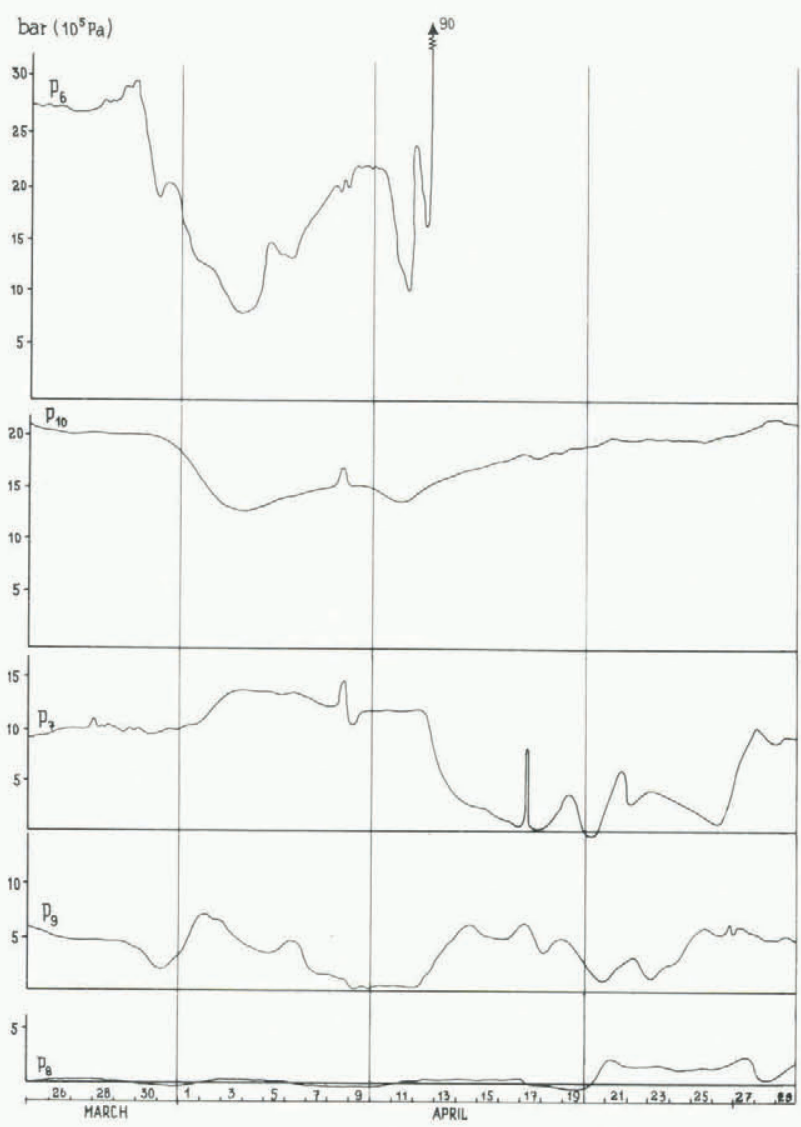

Fig.14. Pressure recordings in the period when $P_{6}$ was destroyed by a boulder.

ice in the lee of the obstacle lacks water for refreezing, and thus cannot warin up.

\section{CONCLUSIONS}

Since the main water intake under Bondhusbreen came into operation, almost all of the available water has been captured. In the spring, meltwater first enters the tunnel system through numerous simall drill holes and in small streains through the larger intakes. Within a few days, however, it concentrates in one or two main streams at intakes (1) and (3), with minor drainage elsewhere. About $90 \%$ of the eroded material passing this cross-section of the glacier is transported by the meltwater while the rest is carried englacially in the basal ice.

There are large local variations in ice movement along the glacier sole. In leeward positions, ice masses can be stagnant with almost equal pressure in all directions for large parts of the year. As water discharge increases in the summer, however, ice in these locations becomes more active. Elsewhere a general ice velocity of $80 \mathrm{~mm} \mathrm{~d}-1$ is observed, with consistent differences in pressure between the upper and lower sides of obstacles. Pressure of about 28 bar occurred on the up-glacier side; very little pressure was recorded in leeward positions of an artificial obstacle.

During the course of one experiment a large boulder, approximately $0.7 \mathrm{~m}$ in diameter, is inferred to have moved across one of the pressure sensors. The boulder moved with a speed of about $40 \mathrm{~mm} \mathrm{~d}^{-1}$, and was preceded by a low-pressure zone about $0.5 \mathrm{~m}$ long. The boulder exerted a pressure greater than 90 bar on the sensor.

Temperature measurements, unfortunately, were less successful. The temperature differences $\Delta T$ were one order of magnitude less than expected, in relation to the observed differences in pressure $\Delta P$. 


\section{ACKNOWLEDGMENTS}

The project was financed by Norges Vassdragsog Elektrisitetsvesen (NVE) and Norges TekniskNaturvitenskapelige Forskningsråd (NTNF) while the cooperating institutions have contributed in other ways. Support from NVE-Vestlandsverkene has been of invaluable help in carrying out the investigations.

The authors extend their thanks to all persons and institutions who have given assistance in the project. Special thanks are due to Dr Roger L Hooke who read the manuscript carefully and improved the final text significantly.

\section{REFERENCES}

Andersen J L, Sollid J L 1971 Glacial chronology and glacial geomorphology in the marginal zones of the glaciers, Midtdalsbreen and Nigardsbreen, south Norway. Norsk Geografisk Tidsskrift 25(1): 1-38

Anderson R S, Hallet B, Walder J, Aubry B F 1982 Observations in a cavity beneath Grinnel Glacier. Earth Surface Processes and Landforms 7(1): 63-70

Boulton G S, Morris E M, Armstrong A A, Thomas A 1979 Direct measurement of stress at the base of a glacier. Journal of Glaciology 22(86): 3-24 Carol H 1947 The formation of roches moutonnees. Joumal of Glaciology 1(1): 57-59

Haakensen N (ed) 1975 Materialtransportundersøkelser i norske bre-elver 1973. Norges Vassdrags- og Elektrisitetsvesen. Vassdragsdirektoratet. Hydrologisk Avdeling. Rapport 4-75

Hagen J O (ed) 1977 Glasiologiske undersøkelser i Norge 1976. Norges Vassdrags-og Elektrisitetsvesen. Vassdragsdirektoratet. Hydrologisk Avdeling. Rapport 7-77

Kamb W B 1970 Sliding motion of glaciers: theory and observation. Reviews of Geophysics and Space Physics 8(4): 673-728

Kjeldsen 0 (ed) 1975 Materialtransportundersøkelser i norske bre-elver 1974 . Norges Vassdrags- og Elektrisitetsvesen. Vassdragsdirektoratet. Hydrologisk Avdeling. Rapport 3-75

Kjeldsen 0 (ed) 1979 Materialtransportundersøkelser $i$ norske bre-elver 1978 . Norges Vassdrags- og Elektrisitetsvesen. Vassdragsdirektoratet. Hydrologisk Avdeling. Rapport 3-79

Kjeldsen 0 (ed) 1980 Materialtransportundersøkelser i norske bre-elver 1979. Norges Vassdrags- og Elektrisitetsvesen. Vassdragsdirektoratet. Hydrologisk Avdeling. Rapport 1-80

Kjeldsen 0 (ed) 1981 Materialtransportundersøkelser $i$ norske bre-elver 1980. Norges Vassdrags-og Elektrisitetsvesen. Vassdragsdirektoratet. Hydrologisk Avdeling. Rapport 4-81

Østrem G, Pytte R (eds) 1968 Glasiologiske undersøkelser i Norge 1967. Norges Vassdrags-og Elektrisitetsvesen. Vassdragsdirektoratet. Hydrologisk Avdeling. Rapport 4-68

Pytte R 1963 Materialhusholdningen for en del av Folgefonni 1963. Norges Vassdrags-og Elektrisitetsvesen. Vassdragsdirektoratet. Hydrologisk Avdeling. Rapport [unnumbered]

Pytte R (ed) 1967 Glasio-hydrologiske undersøkelser $i$ Norge 1966. Norges Vassdrags-og Elektrisitetsvesen. Vassdragsdirektoratet. Hydrologisk Avdeling. Rapport 2-67

Pytte R (ed) 1969 Glasiologiske undersøkelser i Norge 1968. Norges Vassdrags- og Elektrisitetsvesen. Vassdragsdirektoratet. Hydrologisk Avdeling. Rapport 5-69

Pytte R, Liestøl 0 (eds) 1966 Glasio-hydrologiske undersøkelser $i$ Norge 1965. Norges Vassdrags- og Elektrisitetsvesen. Vassdragsdirekt oratet. Hydrologisk Avdeling. Arsrapport fra Brekontoret

Pytte R, Østrem G (eds) 1965 Glasio-hydrologiske undersøkelser i Norge 1964. Norges Vassdrags- og Elektrisitetsvesen. Hydrologisk Avdeling. Meddelelse 14
Robin G de Q 1976 Is the basal ice of a temperate glacier at the pressure melting point? Jourmal of Glaciology 16(74): 183-196

Sollid J L 1980 The glacier forefield. In Orheim 0 (ed) Glaciation and deglaciation in central Nomway. 0s1o, Norsk Polarinstitutt: $34-39$

Theakstone WH 1979 Observations within cavities at the bed of the glacier Østerdalsisen, Norway. Journal of Glaciology 23(89): 273-281

Tvede A M (ed) 1973 Glasiologiske undersøkelser $i$ Norge 1971. Norges Vassdrags-og Elektrisitetsvesen. Vassdragsdirektoratet. Hydrologisk Avdeling. Rapport 2-73

Vivian R 1980 The nature of the ice-rock interface: the results of investigation on $20000 \mathrm{~m}$ of the rock bed of temperate glaciers. Joumal of Glaciology 25(92): 267-277

Weertman J 1972 General theory of water flow at the base of a glacier or ice sheet. Reviews of Geophysics and Space Physics 10(1): 287-333

Wold B, Haakensen N (eds) 1978 Glasiologiske undersøkelser $i$ Norge 1977 . Norges Vassdrags- og Elektrisitetsvesen. Vassdragsdirektoratet. Hydrologisk Avdeling. Rapport 3-78

Wold B, Østrem G 1979[a] Morphological activity of a diverted glacier stream in western Norway. Geojournal 3(4): 345-349

Wold B, Østrem G 1979[b] Subglacial constructions and investigations at Bondhusbreen, Norway. Journal of Glaciology 23(89): 363-379

Ziegler T (ed) 1974 Material transportundersøkelser $i$ norske bre-elver 1972. Norges Vassdrags- og Elektrisitetsvesen. Vassdragsdirektoratet. Hydrologisk Avdeling. Rapport 2-74 